\title{
Trypanocidal Terpenoids from Laurus nobilis $\mathrm{L}$.
}

\author{
Nahoko Uchiyama, ${ }^{a}$ Keiji Matsunaga, ${ }^{a}$ Fumiyuki Kiuchi, ${ }^{*}, a$ Gisho Honda, ${ }^{a}$ Akiko Tsubouchi, ${ }^{b}$ \\ Junko NAKAJIMA-SHIMADA, ${ }^{b}$ and Takashi AOKI ${ }^{b}$ \\ ${ }^{a}$ Graduate School of Pharmaceutical Sciences, Kyoto University; 46-29 Yoshida, Sakyo-ku, Kyoto 606-8501, Japan: and \\ ${ }^{b}$ School of Medicine, Juntendo University; 2-1-1 Hongo, Bunkyo-ku, Tokyo 113-8421, Japan. \\ Received July 4, 2002; accepted August 10, 2002
}

Trypanocidal constituents of dried leaves of Laurus nobilis L. (Lauraceae) were examined. Activity-guided fractionation of the methanol extract resulted in the isolation of two guaianolides, dehydrocostus lactone (1) and zaluzanin D (2), and a new $p$-menthane hydroperoxide, $(1 R, 4 S)$-1-hydroperoxy-p-menth-2-en-8-ol acetate (3). The minimum lethal concentrations of these compounds against epimastigotes of Trypanosoma cruzi were 6.3, 2.5, and $1.4 \mu \mathrm{M}$, respectively.

Key words Laurus nobilis; Trypanosoma cruzi; p-menthane hydroperoxide; guaianolide; Lauraceae

Trypanosoma cruzi, a parasitic protozoan of Zoomastigophoria, is the etiologic agent of Chagas' disease which is endemic in Central and South America. ${ }^{1)}$ In our screening work on medicinal plants used in Asian counties for trypanocidal activity, extracts of the dried leaves of Laurus nobilis L. (Lauraceae) showed strong trypanocidal activity against epimastigotes of $T$. cruzi. Leaves of L. nobilis are used as a spice known as laurel or bay leaf. They are also used as a folk medicine for rheumatism and scabies. ${ }^{2}$ Although some biological activities such as inhibition of elevation of blood ethanol level in ethanol-loaded rat ${ }^{3)}$ inhibition of nitric oxide production in lipopolysaccharide-activated mouse peritoneal macrophages, ${ }^{4)}$ induction of glutathione $S$ transferase activity, ${ }^{5)}$ and nematocidal activity ${ }^{6}$ were reported for the constituents of $L$. nobilis, nothing has been reported on anti-protozoan constituents of this plant. Here, we report the isolation and identification of trypanocidal constituents of L. nobilis.

\section{Results and Discussion}

Dried leaves of Laurus nobilis were successively extracted with hexane, $\mathrm{CHCl}_{3}$ and $\mathrm{MeOH}$, and each extract was tested for anti-trypanosomal effect by the HeLa cell infection assay. ${ }^{7)} \mathrm{As}$ the $\mathrm{CHCl}_{3}$ and $\mathrm{MeOH}$ extracts inhibited infection and proliferation of T. cruzi, and the $\mathrm{MeOH}$ extract formed the major part of the extracts, the $\mathrm{MeOH}$ extract was further fractionated under the guidance of in vitro trypanocidal activity against epimastigotes of $T$. $c r u z i{ }^{8)}$ The $\mathrm{MeOH}$ extract was suspended in aqueous $\mathrm{MeOH}$ and fractionated into hexane soluble, AcOEt soluble, and water soluble fractions. Since the AcOEt soluble fraction showed the strongest activity, it was fractionated by silica gel column chromatography to give three trypanocidal compounds $(\mathbf{1}-\mathbf{3})$. These compounds were also isolated from the $\mathrm{CHCl}_{3}$ extracts.

Compounds $\mathbf{1}$ and $\mathbf{2}$ were obtained as colorless needles from hexane, $\mathrm{mp} 58-60^{\circ} \mathrm{C}$, and as a colorless oil, respectively. The ${ }^{1} \mathrm{H}$ - and ${ }^{13} \mathrm{C}$-NMR spectra indicated that both compounds were guaiane-type sesquiterpene with three exocyclic methylene moieties. Based on comparisons of the spectral data with those reported, compounds $\mathbf{1}$ and $\mathbf{2}$ were identified with dehydrocostus lactone $(\mathbf{1})^{9)}$ and zaluzanin D (2) ${ }^{10)}$ respectively.

Compound 3 was obtained as colorless needles from petroleum ether, $\mathrm{mp} 87.5-88.5^{\circ} \mathrm{C}$. The ${ }^{13} \mathrm{C}-\mathrm{NMR}$ spectrum showed that 3 was a monoterpene with two oxygen-bearing carbons $\left(\delta_{\mathrm{C}} 78.6,84.4\right)$ and an acetoxy group $\left(\delta_{\mathrm{C}} 22.5\right.$, 170.6). The ${ }^{1} \mathrm{H}-\mathrm{NMR}$ spectrum showed the presence of three singlet methyls $\left[\delta_{\mathrm{H}} 1.34,1.39,1.44(\right.$ each $\left.3 \mathrm{H}, \mathrm{s})\right]$, an acetoxy group $\left[\delta_{\mathrm{H}} 2.00(3 \mathrm{H}, \mathrm{s})\right]$, and a cis olefin $\left[\delta_{\mathrm{H}} 5.65(1 \mathrm{H}\right.$, ddd, $J=10.0,2.5,1.5 \mathrm{~Hz}), 5.92(1 \mathrm{H}, \mathrm{brdd}, J=10.0,1.5 \mathrm{~Hz})]$. The molecular formula $\mathrm{C}_{12} \mathrm{H}_{20} \mathrm{O}_{4}$, suggested by a weak molecular ion at $m / z 229\left(\mathrm{MH}^{+}\right)$in CI-MS, together with the relatively large chemical shift of the non-acetoxy oxygen-bearing carbon $\left(\delta_{\mathrm{C}} 78.6\right)$ indicated the presence of a hydroperoxy group. Comparison of ${ }^{13} \mathrm{C}$-NMR data with those of known monoterpenes suggested that $\mathbf{3}$ had a $p$-menthane-type skeleton and analyses of ${ }^{1} \mathrm{H}-{ }^{1} \mathrm{H}$ correlation spectroscopy (COSY), ${ }^{1} \mathrm{H}$-detected heteronuclear multiple quantum coherence (HMQC) and heteronuclear multiple bond connectivity (HMBC) spectra (Fig. 1) revealed the structure to be 1-hydroperoxy- $p$ menthan-2-en-8-ol acetate. Treatment of 3 with $\mathrm{PPh}_{3}$ gave an acetoxy alcohol 4, which showed oxygen-bearing carbons at $\delta_{\mathrm{C}} 67.0(\mathrm{C}-1)$ and $\delta_{\mathrm{C}} 84.4(\mathrm{C}-8)$. This confirmed that 3 had a hydroperoxy and an acetoxy group at positions 1 and 8 , respectively. Since nuclear Overhauser effect (NOE) experiments did not provide conclusive stereochemical information, the stereochemistry of $\mathbf{3}$ was determined by chemical correlations. Photo-oxidation ${ }^{11)}$ of $d$-limonene followed by reduction with $\mathrm{PPh}_{3}$ gave $(1 S, 4 R)$ - $p$-mentha-2,8-dien-1-ol (5, $\left.[\alpha]_{\mathrm{D}}=+60.8^{\circ}\right)$ and $(1 R, 4 R)-p$-mentha-2,8-dien-1-ol (6, $[\alpha]_{\mathrm{D}}=+186.4^{\circ}$ ). Oxymercuration of 5 followed by treatment with $\mathrm{NaBH}_{4}$ gave $(1 S, 4 R)-p$-mentha-2-en-1,8-diol (7, $[\alpha]_{\mathrm{D}}=-28.0^{\circ}$ ). The ${ }^{1} \mathrm{H}-$ and ${ }^{13} \mathrm{C}-\mathrm{NMR}$ spectra of 7 were identical with those of the diol $\mathbf{8}$, which was derived from $\mathbf{3}$ by alkaline hydrolysis followed by reduction with $\mathrm{PPh}_{3} .{ }^{12}$ This result established that the relative stereochemistry of $\mathbf{3}$ is identical with that of $\mathbf{7}$. However, the diols $\mathbf{7}$ and $\mathbf{8}$ showed different retention times on GC-MS analysis with chiral capillary column, revealing an enantiomeric relationship between them. ${ }^{13)}$ Thus, the structure of $\mathbf{3}$ was concluded to be $(1 R, 4 S)$-1-hydroperoxy- $p$-menth-2-en- 8 -ol acetate. A sesquiterpene hydroperoxide, verlotorin, has been isolated from L. nobilis. ${ }^{14)}$ However, this is the first report of the isolation of a monoterpene hydroperoxide from this plant.

Compounds $\mathbf{1}-\mathbf{3}$ showed strong trypanocidal activity against epimastigotes of $T$. cruzi with minimum lethal concentrations (MLCs) of $6.3 \mu \mathrm{M}(\mathbf{1}), 2.5 \mu \mathrm{M}$ (2), and $1.4 \mu_{\mathrm{M}}$ (3). The activities were stronger than that of the anthelmintic 


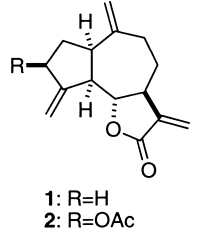<smiles>CC1(C)CCCCC12CCCC2</smiles>

3: $\mathrm{R}_{1}=\mathrm{OH} ; \mathrm{R}_{2}=\mathrm{Ac} \quad d$-limonen 4: $R_{1}=H ; R_{2}=A C$ 8: $R_{1}=R_{2}=H$
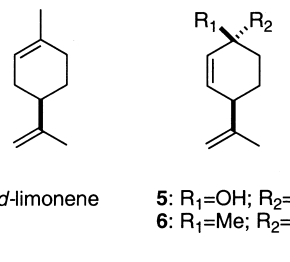

5: $\mathrm{R}_{1}=\mathrm{OH} ; \mathrm{R}_{2}=\mathrm{Me}$ 6: $\mathrm{R}_{1}=\mathrm{Me} ; \mathrm{R}_{2}=\mathrm{OH}$

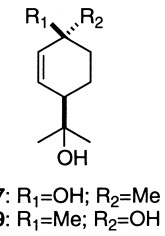

Chart 1

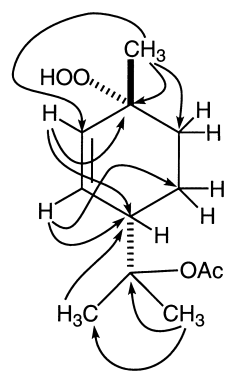

Fig. 1. Selected HMBC Correlations in $\mathbf{3}$

Table 1. Anti-trypanosomal Activity of Compounds $\mathbf{1}-\mathbf{3}$ against $T$. cruzi in the HeLa Infection Assay at $1 \mu \mathrm{g} / \mathrm{ml}$

\begin{tabular}{ccc}
\hline \hline Compound & $\begin{array}{c}\text { Inhibition of infection } \\
(\%)\end{array}$ & $\begin{array}{c}\text { Inhibition of proliferation } \\
(\%)\end{array}$ \\
\hline $\mathbf{1}$ & 74 & 75 \\
$\mathbf{2}$ & -8 & 38 \\
$\mathbf{3}$ & 98 & 83 \\
Allopurinol & 42 & 42 \\
\hline
\end{tabular}

monoterpene endoperoxide, ascaridole $(\mathrm{MLC}=23 \mu \mathrm{M})$ and were comparable to those of monoterpene hydroperoxides isolated from Chenopodium ambrosioides. ${ }^{8)}$ In the HeLa cell infection assay, compound $\mathbf{3}$ very strongly inhibited the infection of the trypomastigotes at $1 \mu \mathrm{g} / \mathrm{ml}$ (Table 1). Dehydrocostus lactone (1) also significantly inhibited the infection at $1 \mu \mathrm{g} / \mathrm{ml}$, whereas zaluzanin D (2) did not inhibit the infection at the same concentration.

Several sesquiterpene lactones having an $\alpha, \beta$-unsaturated $\gamma$-lactone moiety (15-deoxygoyazensolide, ${ }^{15}$ dehydrozaluzanin $\left.\mathrm{C},{ }^{16}\right)$ lychnopholide ${ }^{17)}$ naematolin, ${ }^{18)}$ dehydroleucodine $^{19)}$ ) have been reported to show trypanocidal activity. Brengio et al. reported that the effect of dehydroleucodine was irreversible, but could be blocked by simultaneous addition of a thiol compound. ${ }^{19)}$ This suggests that the trypanocidal activity of this group of compounds relies on covalent bond formation of the $\alpha, \beta$-unsaturated $\gamma$-lactone moiety with nucleophiles which are essential for the life of the parasite. One possible target is the trypanothione (1,8-bis-glutathionyl spermidine) redox system. ${ }^{20-22)}$ Trypanosomes are known to be sensitive to oxidative stresses. As a defense against these stresses, they use trypanothione whose counterpart in mammalian cells is glutathione. $\alpha, \beta$-Unsaturated $\gamma$-lactones will react with -SH groups of trypanothione and of enzymes involved in trypanothione cycle, ${ }^{23)}$ thus inactivating the defense system and exposing the parasite to oxidative damage. For hydroperoxide 3, reactive oxygen species derived from the hydroperoxy moiety may be responsible for the trypanocidal activity.

\section{Experimental}

General Melting points were determined on a Yanagimoto micro melting point apparatus. Optical rotation $\left([\alpha]_{\mathrm{D}}\right)$ was measured on a JASCO DIP370 polarimeter. ${ }^{1} \mathrm{H}$ - and ${ }^{13} \mathrm{C}$-NMR spectra were measured on a JEOL JNMLA500 spectrometer with TMS as an internal standard and chemical shifts were recorded in $\delta$ ppm. Fuji Silysia BW-127ZH silica gel was used for column chromatography.

Plant Materials Dried leaves of Laurus nobilis were purchased from Tochimoto Tenkaido.

Extraction and Isolation The dried leaves $(225 \mathrm{~g})$ were successively extracted with hexane, $\mathrm{CHCl}_{3}, \mathrm{MeOH}(3$ times $\times 21)$ at room temperature overnight. Each extract was concentrated to dryness to give hexane $(3.6 \mathrm{~g})$, $\mathrm{CHCl}_{3}(5.8 \mathrm{~g})$, and $\mathrm{MeOH}(53.4 \mathrm{~g})$ extracts. The $\mathrm{MeOH}$ extract $(53.4 \mathrm{~g})$ was suspended in $700 \mathrm{ml}$ of aqueous $\mathrm{MeOH}$ and extracted with hexane $(250 \mathrm{ml} \times 3$ times). The aqueous $\mathrm{MeOH}$ layer was concentrated to $c a$. $100 \mathrm{ml}$, diluted with water and extracted with AcOEt $(250 \mathrm{ml} \times 3$ times $)$ to give AcOEt soluble (13.5 g) and water soluble (34.3 g) fractions. The AcOEt soluble fraction was applied to a silica gel column and eluted with hexane-acetone $9: 1$ (fr. 1, $127 \mathrm{mg}$; fr. 2, $40 \mathrm{mg}$; fr. 3, $603 \mathrm{mg}$; fr. 4, $187 \mathrm{mg}$ ), $4: 1$ (fr. 5, $408 \mathrm{mg}$; fr. $6,1.1 \mathrm{~g}$; fr. $7,330 \mathrm{mg}$ ), $7: 3$ (fr. $8,646 \mathrm{mg}$; fr. $9,2.4 \mathrm{~g}$ ), acetone (fr. 10, $3.8 \mathrm{~g}$ ), and $\mathrm{MeOH}$ (fr. 11, $3.3 \mathrm{~g}$ ), among which fractions 2, 3 , 5,6 , and 8 showed trypanocidal activity at $25 \mu \mathrm{g} / \mathrm{ml}$. Fractions 3,5 , and 6 were separately purified by silica gel column chromatography to give compounds 1 (dehydrocostus lactone, $83 \mathrm{mg}$ ), ${ }^{9)} \mathbf{2}$ (zaluzanin D, $245 \mathrm{mg}$ ), ${ }^{10)}$ and 3 $(15 \mathrm{mg})$, respectively. Fraction 8 also gave zaluzanin D $(2,239 \mathrm{mg})$.

Compound 3 : colorless needles from petroleum ether, $\mathrm{mp} 87.5-88.5^{\circ} \mathrm{C}$. $[\alpha]_{\mathrm{D}}=-7.9^{\circ}(c=0.61, \mathrm{EtOH}) .{ }^{1} \mathrm{H}-\mathrm{NMR}\left(\mathrm{CDCl}_{3}, 500 \mathrm{MHz}\right) \delta: 1.34(3 \mathrm{H}, \mathrm{s}$, $\left.\mathrm{CH}_{3}-7\right), 1.39\left(3 \mathrm{H}, \mathrm{s}, \mathrm{CH}_{3}-9\right), 1.41(1 \mathrm{H}, \mathrm{m}, \mathrm{H}-6), 1.44\left(3 \mathrm{H}, \mathrm{s}, \mathrm{CH}_{3}-10\right), 1.58$ $\left(2 \mathrm{H}, \mathrm{m}, \mathrm{CH}_{2}-5\right), 2.00(3 \mathrm{H}, \mathrm{s}, \mathrm{Ac}), 2.20(1 \mathrm{H}, \mathrm{dtd}, J=14.0,3.5,1.5 \mathrm{~Hz}, \mathrm{H}-6)$, $2.80(1 \mathrm{H}, \mathrm{m}, \mathrm{H}-4), 5.65$ (1H, ddd, $J=10.0,2.5,1.5 \mathrm{~Hz}, \mathrm{H}-2), 5.92(1 \mathrm{H}$, br dd, $J=10.0,1.5 \mathrm{~Hz}, \mathrm{H}-3), 7.94(1 \mathrm{H}, \mathrm{s}, \mathrm{OOH}) .{ }^{13} \mathrm{C}-\mathrm{NMR}\left(\mathrm{CDCl}_{3}, 125 \mathrm{MHz}\right)$ $\delta: 20.1(\mathrm{C}-5), 22.5\left(\mathrm{COCH}_{3}\right), 23.1(\mathrm{C}-10), 23.7(\mathrm{C}-9), 24.8(\mathrm{C}-7), 31.7(\mathrm{C}-$ 6), 44.4 (C-4), 78.6 (C-1), 84.4 (C-8), 129.9 (C-2), 133.7 (C-3), 170.6 $\left(\underline{\mathrm{COCH}}_{3}\right) . \mathrm{CI}-\mathrm{MS} m / z: 229\left(\mathrm{MH}^{+}, 1\right), 211\left(\mathrm{MH}^{+}-18,4\right), 195$ (10), 153 (17), 151 (13), 135 (100).

Reduction of $\mathbf{3}$ with $\mathbf{P P h}_{3}$ Compound $\mathbf{3}(4.5 \mathrm{mg})$ dissolved in ether $(1 \mathrm{ml})$ was treated with $\mathrm{PPh}_{3}(8.5 \mathrm{mg})$ at room temperature for $20 \mathrm{~min}$. The mixture was concentrated to dryness and the residue was chromatographed over silica gel to give an acetoxy alcohol $4(3.4 \mathrm{mg})$.

Compound 4: Colorless oil. $[\alpha]_{\mathrm{D}}=+11.5^{\circ}\left(c=0.17, \mathrm{CHCl}_{3}\right) .{ }^{1} \mathrm{H}-\mathrm{NMR}$ $\left(\mathrm{CDCl}_{3}, 500 \mathrm{MHz}\right) \delta: 1.29,1.41,1.46\left(\right.$ each $\left.3 \mathrm{H}, \mathrm{s}, \mathrm{CH}_{3}-7,9,10\right), 1.48(1 \mathrm{H}$, m), $1.58(1 \mathrm{H}, \mathrm{m}), 1.68(1 \mathrm{H}, \mathrm{m}), 1.87(1 \mathrm{H}, \mathrm{m}), 2.00(3 \mathrm{H}, \mathrm{s}, \mathrm{Ac}), 2.75(1 \mathrm{H}$, $\mathrm{m}), 5.73(2 \mathrm{H}$, t-like, $J=11 \mathrm{~Hz}, \mathrm{H}-2,3) .{ }^{13} \mathrm{C}-\mathrm{NMR}\left(\mathrm{CDCl}_{3}, 125 \mathrm{MHz}\right) \delta: 20.3$ (C-5), $22.6\left(\mathrm{COCH}_{3}\right), 23.1$ (C-10), 23.8 (C-9), 29.9 (C-7), 37.1 (C-6), 44.5 (C-4), 67.0 (C-1), 84.4 (C-8), 129.8 (C-2), 134.7 (C-3), $170.6\left(\mathrm{COCH}_{3}\right)$.

Photo-oxidation and Reduction of $\boldsymbol{d}$-Limonene A stirred solution of $d$-limonene $(2 \mathrm{~g})$ and Rose Bengal $(29 \mathrm{mg})$ in $\mathrm{MeOH}(29 \mathrm{ml})$ was irradiated by a high pressure mercury lamp (Riko Kagaku, UV-100HA) under oxygen atmosphere at $0^{\circ} \mathrm{C}$ for $8.5 \mathrm{~h}$. The mixture was concentrated to dryness, and the residue was dissolved in ether $(30 \mathrm{ml})$ and treated with $\mathrm{PPh}_{3}(2.6 \mathrm{~g})$ at room temperature for $1 \mathrm{~h}$. The mixture was concentrated to dryness and the residue was fractionated by repeated silica gel column chromatography with hexane-AcOEt $(4: 1)$ to give $(1 S, 4 R)$ - $p$-mentha-2,8-dien-1-ol $(\mathbf{5}, 299 \mathrm{mg}$, $13.4 \%)$ and $(1 R, 4 R)$ - $p$-mentha-2,8-dien-1-ol (6, $53 \mathrm{mg}, 5.3 \%)$.

$(1 S, 4 R)$ - $p$-Mentha-2,8-dien-1-ol (5): Colorless oil. $[\alpha]_{\mathrm{D}}=+60.8^{\circ}$ $\left(c=0.62, \mathrm{CHCl}_{3}\right)\left(\right.$ lit., $\left.+67.3^{\circ}\right) .{ }^{11)}{ }^{1} \mathrm{H}-\mathrm{NMR}\left(\mathrm{CDCl}_{3}, 500 \mathrm{MHz}\right) \delta: 1.30(3 \mathrm{H}$, $\left.\mathrm{s}, \mathrm{CH}_{3}-7\right), 1.61\left(2 \mathrm{H}, \mathrm{m}\right.$, overlapped, H-5, H-6), $1.74\left(3 \mathrm{H}, \mathrm{br} \mathrm{s}, \mathrm{CH}_{3}-10\right), 1.77$ (1H, m, H-5), 1.85 (1H, m, H-6), $2.66(1 \mathrm{H}, \mathrm{m}, \mathrm{H}-4), 4.75$ (1H, br s, Ha-9), $4.78(1 \mathrm{H}$, quintet., $J=1.5 \mathrm{~Hz}, \mathrm{Hb}-9), 5.66(1 \mathrm{H}$, ddd, $J=10.1,2.2,1.0 \mathrm{~Hz}, \mathrm{H}-$ 3), $5.71(1 \mathrm{H}$, ddd, $J=10.1,2.2,1.3 \mathrm{~Hz}, \mathrm{H}-2) .{ }^{13} \mathrm{C}-\mathrm{NMR}\left(\mathrm{CDCl}_{3}, 125 \mathrm{MHz}\right)$ $\delta$ : 20.8 (C-10), 24.9 (C-5), 29.4 (C-7), 36.7 (C-6), 43.4 (C-4), 67.4 (C-1), 110.6 (C-9), 132.1 (C-3), 133.9 (C-2), 148.1 (C-8). 
$(1 R, 4 R)$ - $p$-Mentha-2,8-dien-1-ol $\quad(6)$ : Colorless $\quad$ oil. $\quad[\alpha]_{\mathrm{D}}=+186.4^{\circ}$ $\left(c=0.97, \mathrm{CHCl}_{3}\right)\left(\right.$ lit.,$\left.+163.8^{\circ}\right) .{ }^{11}{ }^{1} \mathrm{H}-\mathrm{NMR}\left(\mathrm{CDCl}_{3}, 500 \mathrm{MHz}\right) \delta: 1.29$ $\left(3 \mathrm{H}, \mathrm{s}, \mathrm{CH}_{3}-7\right), 1.56(1 \mathrm{H}, \mathrm{m}, \mathrm{Ha}-5), 1.66(1 \mathrm{H}$, ddd, $J=12.8,9.5,2.8 \mathrm{~Hz}, \mathrm{Ha}-$ 6), $1.74\left(3 \mathrm{H}\right.$, br s, $\left.\mathrm{CH}_{3}-10\right), 1.79$ (1H, ddd, $\left.J=12.8,8.9,2.8 \mathrm{~Hz}, \mathrm{Hb}-6\right), 1.90$ (1H, m, Hb-5), $2.74(1 \mathrm{H}, \mathrm{m}, \mathrm{H}-4), 4.67(1 \mathrm{H}, \mathrm{br}, \mathrm{Ha}-9), 4.78$ (1H, quintet, $J=1.6 \mathrm{~Hz}, \mathrm{Hb}-9), 5.61(1 \mathrm{H}, \mathrm{dd}, J=10.1,3.4 \mathrm{~Hz}, \mathrm{H}-3), 5.70(1 \mathrm{H}, \mathrm{dd}, J=10.1$, $2.1 \mathrm{~Hz}, \mathrm{H}-2) .{ }^{13} \mathrm{C}-\mathrm{NMR}\left(\mathrm{CDCl}_{3}, 125 \mathrm{MHz}\right) \delta: 21.2(\mathrm{C}-10), 25.0(\mathrm{C}-5), 28.9$ (C-7), 36.1 (C-6), 42.5 (C-4), 68.6 (C-1), 110.9 (C-9), 130.8 (C-3), 134.5 (C-2), 147.2 (C-8).

Oxymercuration of (1S,4R)-p-Mentha-2,8-dien-1-ol (5) To a solution of mercury (II) acetate in water $(2 \mathrm{ml})$, THF $(2 \mathrm{ml})$ and then a solution of 5 $(64 \mathrm{mg})$ in THF $(1 \mathrm{ml})$ were added, then the mixture was stirred at room temperature for $10 \mathrm{~min}$. To this mixture, $3 \mathrm{M} \mathrm{NaOH}(2 \mathrm{ml})$, and then $0.5 \mathrm{M}$ $\mathrm{NaBH}_{4}$ in $3 \mathrm{M} \mathrm{NaOH}(1 \mathrm{ml})$ were added and the mixture was stirred for $5 \mathrm{~min}$. The mixture was saturated with $\mathrm{NaCl}$ and the THF layer was separated, dried over anhydrous $\mathrm{MgSO}_{4}$, and concentrated to dryness. The residue was purified by column chromatography on silica gel to give (1S,4R)-p-mentha-2-en-1,8-diol (7, $14 \mathrm{mg}, 19.6 \%)$.

$(1 S, 4 R)$ - $p$-Mentha-2-en-1,8-diol (7): Colorless oil. $[\alpha]_{\mathrm{D}}=-28.0^{\circ}(c=1.4$, $\mathrm{CHCl}_{3}$ ). ${ }^{1} \mathrm{H}-\mathrm{NMR}\left(\mathrm{CDCl}_{3}, 500 \mathrm{MHz}\right) \delta: 1.19,1.26$ (each $3 \mathrm{H}, \mathrm{s}, \mathrm{CH}_{3}-9,10$ ), $1.29\left(3 \mathrm{H}, \mathrm{s}, \mathrm{CH}_{3}-7\right), 1.53(2 \mathrm{H}, \mathrm{m}), 1.75(1 \mathrm{H}, \mathrm{m}), 1.88(1 \mathrm{H}, \mathrm{m}), 2.06(1 \mathrm{H}, \mathrm{m}$, $\mathrm{H}-4), 5.77(1 \mathrm{H}, \mathrm{dt}, J=10.1,1.8 \mathrm{~Hz}, \mathrm{H}-3), 5.88(1 \mathrm{H}, \mathrm{dt}, J=10.1,1.8 \mathrm{~Hz}, \mathrm{H}-$ 2). ${ }^{13} \mathrm{C}-\mathrm{NMR}\left(\mathrm{CDCl}_{3}, 125 \mathrm{MHz}\right) \delta$ : $20.4(\mathrm{C}-5), 26.3(\mathrm{C}-9), 28.1$ (C-10), 29.6 (C-7), 37.0 (C-6), 47.0 (C-4), 66.9 (C-1), 72.6 (C-8), 130.0 (C-3), 134.9 (C2).

Hydrolysis and Reduction of Compound 3 A mixture of compound 3 $(0.5 \mathrm{mg})$ in $\mathrm{MeOH}(0.1 \mathrm{ml})$ and $10 \% \mathrm{NaOH}(0.1 \mathrm{ml})$ was stirred at room temperature for $1 \mathrm{~h}$. The mixture was neutralized and applied to a silica gel column, which was eluted with AcOEt to give an alcohol. The alcohol was dissolved in ether $(1 \mathrm{ml})$ and stirred with $\mathrm{PPh}_{3}(1.4 \mathrm{mg})$ at room temperature for $40 \mathrm{~min}$. The mixture was concentrated to dryness and the residue was purified by silica gel column chromatography with hexane: AcOEt $(5: 4)$ to give the diol 8, whose ${ }^{1} \mathrm{H}$ - and ${ }^{13} \mathrm{C}$-NMR spectra were identical with those of $(1 S, 4 R)$ - $p$-mentha-2-en-1,8-diol (7).

GC-MS Analysis with Chiral Capillary Column GC-MS analysis was performed on a Hitachi G-7000M/M-9000 system equipped with a Cyclodex-B chiral capillary column $(0.25 \mathrm{~mm} \times 30 \mathrm{~m}, \mathrm{~J} \& \mathrm{~W})$. GC conditions: column temperature, starting at $40^{\circ} \mathrm{C}, 10^{\circ} / \mathrm{min}$ to $100^{\circ} \mathrm{C}, 5^{\circ} / \mathrm{min}$ to $130^{\circ} \mathrm{C}$, $3 \%$ min to $160^{\circ} \mathrm{C}, 20^{\circ} / \mathrm{min}$ to $220^{\circ} \mathrm{C}$; injector temperature, $100^{\circ} \mathrm{C}$; carrier gas, He; flow rate, $1 \mathrm{ml} / \mathrm{min}$. Retention time: the diol (8) derived from compound 3, $20.68 \mathrm{~min}$; compound 7, $20.92 \mathrm{~min}$. MS conditions: mode, EI; ionization voltage: $15 \mathrm{eV}$. The MS patterns of 7 and 8 were identical; $\mathrm{m} / \mathrm{z}(\%)$ : $152\left(\mathrm{M}^{+}-\mathrm{H}_{2} \mathrm{O}, 1\right), 135$ (13), 110 (33), 96 (25), 95 (98), 92 (18), 80 (100).

Trypanocidal Assay Trypanocidal assay was performed as described previously. ${ }^{8} \mathrm{EtOH}$ was used as a negative control. Ketoconazole and gentian violet were used as positive controls. The MLCs of ketoconazole and gentian violet under this assay condition were $50 \mu \mathrm{m}$ and $6.3 \mu \mathrm{M}$, respectively.

HeLa Infection Assay The HeLa cell infection assay was performed as described previously. ${ }^{7}$ A round coverslip was placed in each well of a $24-$ well plate. Exponentially growing HeLa cells $\left(5 \times 10^{3} \mathrm{cells} / \mathrm{ml} / \mathrm{well}\right)$ were added to each well, followed by incubation at $37^{\circ} \mathrm{C}$ for $2 \mathrm{~d}$ in $5 \% \mathrm{CO}_{2}$ in air. The cells were then infected with $T$. cruzi trypomastigotes $\left(1-2 \times 10^{4}\right.$ parasites/well). A compound to be tested was dissolved in ethanol $(10 \mu 1)$ and added immediately after infection. HeLa cells attached to the coverslip were fixed and stained with Diff-Quik (Kokusai Shiyaku) at day 4 after infection. The coverslip was then transferred upside down to a slide glass, and the cells were finally embedded in HSR solution (Kokusai Shiyaku) for observation under a microscope. The percentage of infected host cells, i.e. those containing more than one amastigote, and the mean number of amastigotes per infected cell were determined by analyzing more than 200 host cells distributed in randomly chosen microscopic fields. Allopurinol was used as a positive control.

Acknowlegements The authors thank Professor K. Tomioka of the
Graduate School of Pharmaceutical Sciences, Kyoto University, for allowing us to use the NMR facilities, and Dr. N. Akimoto of the Faculty of Pharmaceutical Sciences, Kyoto University, for MS measurements. This work was supported in part by a Grant-in-Aid for Scientific Research (No. 11672101) from the Japan Society for the Promotion of Science.

\section{References and Notes}

1) Bastien J. W., "The Kiss of Death, Chagas' Disease in the Americas," The University of Utah Press, Salt Lake City, 1998.

2) Cuo J.-X. (ed.), "International Collation of Traditional and Fork Medicine," Vol. 4, World Scientific Publishing, Singapore, 1997, pp. 1718.

3) Matsuda H., Shimoda H., Uemura T., Yoshikawa M., Bioorg. Med. Chem. Lett., 9, 2647-2652 (1999).

4) Matsuda H., Kagerura T., Toguchida I., Ueda H., Morikawa T., Yoshikawa M., Life Sci., 66, 2151-2157 (2000).

5) Wada K., Ueda N., Sawada H., Amemiya N., Haga M., Natural Medicines, 51, 283-285 (1997).

6) Kiuchi F., Nakamura N., Miyashita N., Nishizawa S., Tsuda Y., Kondo K., Shoyakugaku Zasshi, 43, 279-287 (1989).

7) Nakajima-Shimada J., Hirota Y., Kaneda T., Aoki T., J. Protozool. Res. , 4, 10-17 (1994)

8) Kiuchi F., Itano Y., Uchiyama N., Honda G., Tsubouchi A., NakajimaShimada J., Aoki T., J. Nat. Prod., 65, 509-512 (2002).

9) Taniguchi M., Kataoka T., Suzuki H., Uramoto M., Ando M., Arao K., Magae J., Nishimura T., Otake N., Nagai K., Biosci. Biotech. Biochem., 59, 2064-2067 (1995)

10) Ando M., Kusaka H., Ohara H., Takase K., Yamaoka H., Yanagi Y., J. Org. Chem., 54, 1952-1960 (1989).

11) Schenck G. O., Gollnick K., Buchwald G., Schroeter S., Ohloff G., Liebigs Ann. Chem., 674, 93-118 (1964).

12) The other possible diastereomer 9 was prepared from 6 (y. 33\%) as described for 7. The NMR spectra of $\mathbf{9}$ were different from those of $\mathbf{8}$. Compound 9: colorless prisms (hexane-AcOEt), mp $110-112^{\circ} \mathrm{C}$. ${ }^{1} \mathrm{H}-$ NMR $\left(\mathrm{CDCl}_{3}, 500 \mathrm{MHz}\right) \delta: 1.17,1.22$ (each $\left.3 \mathrm{H}, \mathrm{s}, \mathrm{CH}_{3}-9,10\right), 1.29$ $\left(3 \mathrm{H}, \mathrm{s}, \mathrm{CH}_{3}-7\right), 1.42(1 \mathrm{H}, \mathrm{dt}, J=13.5,3.1 \mathrm{~Hz}, \mathrm{H}-5), 1.65(1 \mathrm{H}, \mathrm{td}, J=13$ $2.8 \mathrm{~Hz}, \mathrm{H}-6), 1.87(1 \mathrm{H}, \mathrm{m}, \mathrm{H}-5), 1.94(1 \mathrm{H}, \mathrm{m}, \mathrm{H}-6), 2.17(1 \mathrm{H}, \mathrm{m}, \mathrm{H}-$ 4), $5.72(1 \mathrm{H}, \mathrm{dt}, J=10.7,1.7 \mathrm{~Hz}, \mathrm{H}-2), 5.75(1 \mathrm{H}, \mathrm{dt}, J=10.7,1.3 \mathrm{~Hz}$, $\mathrm{H}-3) .{ }^{13} \mathrm{C}-\mathrm{NMR}\left(\mathrm{CDCl}_{3}, 125 \mathrm{MHz}\right) \delta: 22.9(\mathrm{C}-5), 26.1$ (C-9), 27.9 (C10), 28.2 (C-7), 38.2 (C-6), 46.9 (C-4), 69.5 (C-1), 72.6 (C-8), 127.8 (C-3), 136.5 (C-2).

13) Compound $\mathbf{8}$ showed positive optical rotation, although no reliable $[\alpha]_{\mathrm{D}}$ value could be determined because of the scarcity of the compound.

14) El-Feraly F. S., Benigni D. A., J. Nat. Prod., 43, 527-530 (1980).

15) Chiari E., de Oliveira A. B., Raslan D. S., Mesquita A. A. L., Tavares K. G., Trans. Roy. Soc. Trop. Med. Hyg., 85, 372-374 (1991).

16) Fournet A., Muñoz V., Roblot F., Hocquemiller R., Cavé A., Gantier J. C., Phytother. Res., 7, 111-115 (1993).

17) de Oliveria A. B., Saúde D. A., Perry K. S. P., Duarte D. S., Raslan D. S., Boaventura M. A. D., Chiari E., Phytother. Res., 10, 292-295 (1996).

18) Inchaustil A., Yaluff G., Arias A. R., Torres S., Ferreria M. E., Nakayama H., Schinini A., Lorenzen K., Anke T., Fournet A., Phytother. Res., 11, 193-197 (1997).

19) Brengio S. D., Belmonte S. A., Guerreiro E., Giordano O. S., Pietrobon E. O., Sosa M. A., J. Parasitol., 86, 407-412 (2000).

20) Fairlamb A. H., Cerami A., Annu. Rev. Microbiol., 46, 695-729 (1992).

21) Schirmer R. H., Müller J. G., Krauth-Siegel R. L., Angew. Chem. Int. Ed. Engl., 34, 141-154 (1995).

22) Sepúlveda-Boza S., Cassels B. K., Planta Med., 62, 98-105 (1996).

23) D'Silva C., Daunes S., Expert Opin. Investig. Drugs, 11, 217-231 (2002). 